HAWAII AGRICULTURAL EXPERIMENT STATION, E. V. WILCOX, Special Agent in Charge.

Bulletin No. 28.

\title{
THE EFFECT OF MANGANESE ON PINEAPPLE PLANTS AND
}

\section{THE RIPENING OF THE PINEAPPLE FRUIT.}

BY

E. V. WILCOX, Special Agent in Charge, AND W. P. KELLEY, Chemist.

U. 8. DEPARTMENT OF AGRICULTURE. 


\section{HAWAII AGRICULTURAL EXPERIMENT STATION, HONOLULU.}

[Under the supervision of A. C. TRuE, Director of the Office of Experiment Stations, United States Department of Agriculture.]

Walter H. Evans, Chief of Division of Insular Stations, Office of Experiment Stations.

\section{STATION STAFF.}

E. V. Wilcox, Special Agent in Charge.

J. Edgar Higgins, Horticulturist.

W. P. Kliley, Chemist.

C. K. McClelland, Agronomist.

D. T. Fullaway, Entomologist.

W. T. McGeorge, Assistant Chemist.

Alice R. Thompson, Assistant Chemist.

C. J. HunN, Assistant Horticulturist.

V. S. HoLt, Assistant in Horticulture.

C. A. SAHR, Assistant in Agronomy.

[Bull. 28]

(2) 


\section{LETTER OF TRANSMITTAL.}

Honolulu, Hawair, May 1, 1912.

SIR: I have the honor to submit herewith and recommend for publication, as Bulletin No. 28 of the Hawaii Agricultural Experiment Station, a paper on the Effect of Manganese on Pineapple Plants, and the Ripening of Pineapple Fruit, prepared jointly by myself and Mr. W. P. Kelley, chemist. Chemical investigation on the cause of yellowing of pineapples on certain soils and on the ripening of the pineapple fruits has been carried on for the past three years, and some of the important results of this investigation are stated in this paper. A microscopic study was made of all the different parts of pineapples for the purpose of learning the structural changes produced by the presence of large quantities of manganese in the soil and the morphological changes which occur in the ripening of the fruit. The anatomical and chemical findings are in rather striking harmony. The practical bearing of these investigations should be of importance in the further development of the pineapple industry.

Respectfully,

E. V. Wilcox, Special Agent in Charge.

Dr. A. C. True,

Director Office of Experiment Stations,

$U$.S. Department of Agriculture, Washington, D.C.

Publication recommended.

A. C. True, Director.

Publication authorized.

JaMes Wilson, Secretary of Agriculture.

[Bull. 28] 



\section{CONTENTS.}

The effect of manganese on pineapple plants $P$ Page.

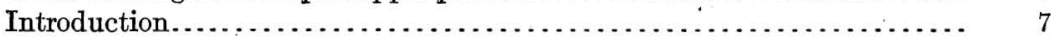

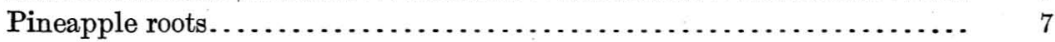

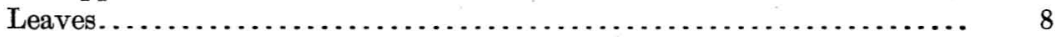

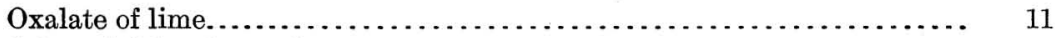

Other visible effects of manganese............................... 11

The chemistry of the pineapple plant......................... 12

The composition of the pineapple plant as affected by manganese......... 13

The ripening of the pineapple fruit................................. 14

The chemistry of ripening................................... 16

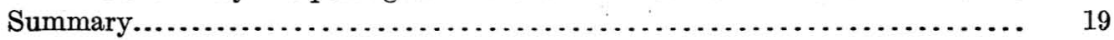

\section{ILLUSTRATIONS.}

Page.

Plate I. Structure of pineapple leaf showing effect of manganese............ 8

II. Cells from pineapple leaves and fruits..................... 8

[Bull. 28]

(5) 



\section{THE EFFECT OF MANGANESE ON PINEAPPLE PLANTS, AND THE RIPENING OF THE PINEAPPLE FRUIT.}

\section{THE EFFECT OF IMANGANESE ON PINEAPPLE PLANTS.}

\section{INTRODUCTION.}

The pineapple belongs to the family Bromeliaceæ, several species of which are of epiphytic habit. With the exception of the black moss of the South which, as its name indicates, has a moss-like habit of growth and small terete branches, the members of this family which we have been able to examine show very similar structure and arrangement of the cellular tissue of the leaves. The pineapple presents certain peculiar habits of growth which constantly remind one of the fact that it belongs to a family of plants in which a number of epiphytic species occur. The family as a whole occurs principally in tropical and subtropical climates and exhibits a power of adaptation to a wide range of conditions of soil and rainfall.

The studies reported in this bulletin were undertaken jointly as a continuation of the work reported by this station regarding the effect of manganese on pineapples, and also regarding some of the points which have been observed in the chemical composition of pineapple fruits in different stages of development. ${ }^{1}$ It will be noticed in studying the results which we have obtained that the anatomical and chemical findings are in remarkable harmony and that they mutually assist in explaining each other.

PINEAPPLE ROOTS.

One of the points which is likely to appear most striking in the study of pineapples in the field is the great variation in the root structures. Under favorable conditions the roots may be several feet in length and may quite fully occupy the soil in all directions from the base of the plant. In pulling up apparently vigorous plants, however, many will be found to have almost no root system, although the aerial portion of the plant appears to be as vigorous as those which possess a well-developed set of roots. Moreover, it is also a striking fact that even on many of the most healthy plants the roots may be nearly all dead and in process of decay, with only here and

1 Hawaii Sta. Bul. 26 ; Press Bul. 23 ; Rpt. 1909, pp. 58-63 ; Rpt. 1910, pp. 41-43, 45-50. 
there a living root covered near its growing tip with root hairs. In the zone of the root where the root hairs occur these structures are remarkably abundant, the large majority of the epidermal cells of the root being developed into hair structures. It is a difficult matter, therefore, to wash the soil away from these portions of the roots without tearing off the root hairs. It is impossible to determine with -certainty the causes which bring about the great variation in the length and number of living roots on plants which seem to be quite vigorous and on normal soils. The proper development of the root system, however, seems to depend largely upon suitable physical conditions in the soil. Where drainage is poor and where the soil becomes packed or puddled below the depth of cultivation, it is impossible for the roots to penetrate and develop as they otherwise might do.

In general it may be said that the root system of pineapples growing on highly manganiferous soils is rather less extensive than that observed on normal soils. The number of small fibrous branches on the main roots is much reduced in manganiferous soils. One of the most striking effects of a high percentage of manganese in the soil is observed in the root tips, which quite generally show rounded swollen ends rather than the pointed tips with rootcaps, such as occur in normal soils. These swollen root tips are almost invariably dead or dying and usually are found in process of decay. It is obvious that they have in all cases ceased growing. In fact, growth is impossible after the swelling occurs, since the roots are then unable to penetrate farther into the soil. In the woody tissue and in the cells immediately under the epidermis of roots growing in manganiferous soil there is a slightly greater tendency toward browning of the cell walls than is the case in normal soils.

LEAVES.

The leaves of the pineapple and other members of the same family with similar habits of growth are attached to the short stems of the plant close together and spread at an angle of $45^{\circ}$, more or less, from the axis of the plant. The edges of the leaves are curved upward, so that a cross section of a leaf is approximately a semicircle.

In the normal pineapple plant the upper surface of the leaf shows a conspicuous red color, which is confined to the central third of the leaf surface. The upward curving of the edges of the leaf naturally divides the upper surface of the leaf into three nearly equal portions, two being upright, one on either side, and the third portion lying at the bottom of the trough. This central or lower third receives the sunlight to a much greater degree than the sides of the leaf, and the development of a red coloring matter in the lower third seems to be

[Bull. 29] 

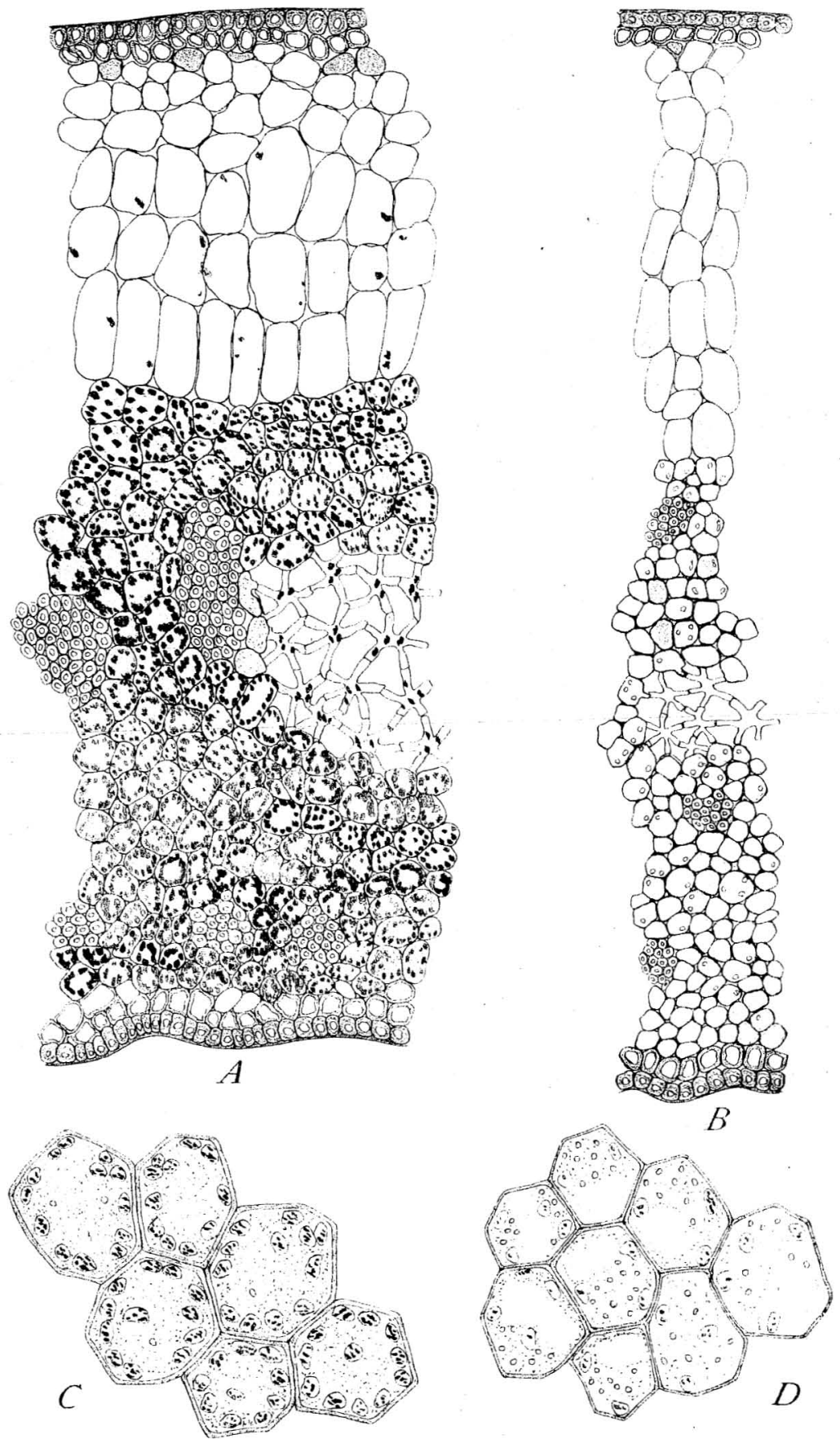

Structure of Pineapple Leaf, Showing Effect of Manganese.

$A$, Cross-section of normal leaf. $\mathrm{X} 60 . \quad B$, Cross-section of leaf from higbly manganiferous soil. $\mathrm{X} 60$. C, Typical cells from spongy parenchyma, normal leaf. X 350 . D, 'Typical cells from spongy parenchyma, manganese leaf. X 350 . 

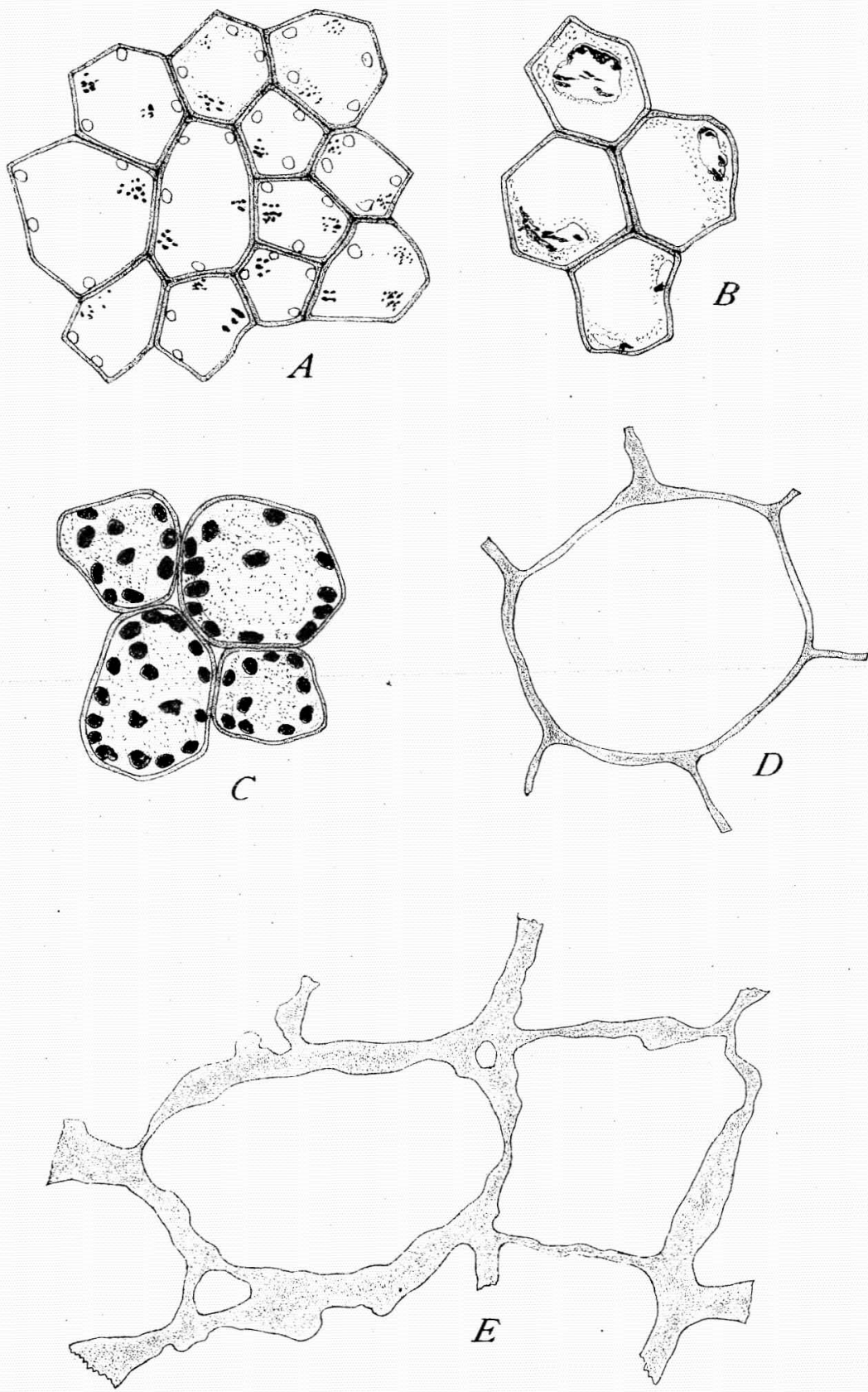

A HOENECO BAITIMORE

CELLS fROM Pineapple LeAVES AND Fruits.

$A$, Spongy parenchyma cells in a pineapple leaf from highly manganiferous soil. $\mathrm{X} 350 . \quad B$ and $C$, Stages in etiolation of similar cells. X 350. D, A cell from pulp of ripe pineapple fruit. X 350 . $E$, Two cells from pulp of green pineapple fruit. $\mathrm{X} 350$. 
directly connected with this fact. It apparently forms a screen which protects the underlying chlorophyll from the intense action of the tropical sun. This hypothesis is borne out by the arrangement of the chlorophyll in the leaves of pineapples and related species of the same family, as will be presently shown.

One of the peculiar features of the pineapple leaf is the apparent absence of stomata. Hundreds of sections were made from pineapple leaves and examined under the microscope, and portions of the epidermis of the upper and under sides of the leaves were carefully examined without finding any true stomata. There are in some parts of the leaves pits in the epidermis in which much-branched scale-like trichomes are attached. These structures are particularly numerous on the under side of the leaf near the base. The trichomes in question are supposed to be connected with the absorption of water.

Running through the leaves parallel to the strands of fibrovascular tissue are strands of branched or stellate cells, which show large intercellular spaces between their branches. These strands lie directly over the pits in the epidermis of the lower side, of the leaf and seem to be connected with transpiration and the absorption of gases. It would appear that the respiratory system of the pineapple is abortive, for when the leaves of Bromelia are studied the development of the strands of branched cells and the stomata is very conspicuous. In this genus there are numerous small tubular masses of branched cells which extend from the general strands of this .tissue to the epidermis of the lower side of the leaf and are directly connected with the stomata, which are arranged very close together in parallel furrows which alternate with ridges on the lower surface of the leaf. In the pineapple, on the other hand, there are no specially modified cells connecting the strands of branched cells with the epidermis. In Greigia, another genus of this family, no branched cells occur in the leaves. The chlorophyll-bearing tissue in this genus is a very thin layer on the lower surface of the leaf, and the respiratory processes appear to go on without the assistance of the stellate cells.

In cross sections of normal pineapple leaves it is at once noticed that from one-fifth to two-fifths of the thickness of the leaf on the upper side is composed of colorless tissue containing cell sap and practically no other cell contents. This tissue, with the exception of one or two layers of cells next to the epidermis, is concerned in the movement and transportation of cell sap. Below the region of the palisade cells lies the spongy parenchyma, which occupies about. three-fifths of the thickness of the leaf of the pineapple, and through which the strands of fibrovascular tissue run lengthwise of the leaf. $50690^{\circ}-$ Bull. $28-12-2$ 
The chlorophyll in the leaves of normal pineapples is nearly all contained in this spongy parenchyma and is therefore protected from the direct sunlight by means of a layer of cells next to the epidermis containing a red coloring matter and by a layer of palisade tissue three or four cells deep. In Bromelia the palisade cells occupy about three-fifths of the thickness of the leaf and in Greigia about four-fifths of the leaf. The layer of delicate palisade cells, showing no cell contents except cell sap, makes it a rather difficult matter to obtain good free-hand sections without injury or disarrangement of the cell structure. The arrangement of the cell structures in. the cross section of a normal pineapple leaf is shown in Plate I, A.

In contrast with the anatomical features of the normal pineapple leaf attention is called to Plate $\mathrm{I}, \mathrm{B}$, which shows a corresponding section of a leaf of a pineapple grown on a highly manganiferous soil. This figure shows the destruction which has taken place in the chlorophyll and the protoplasmic bodies in general. A few small green granules are observed here and there, but the most of the chlorophyll bodies have been disintegrated and have disappeared or at least lost their green coloring:matter. In a few instances it will be observed that the protoplasmic bodies have become discolored with a more or less pronounced brown. The arrangement of the chlorophyll bodies in the normal leaf is shown under higher magnification in the cells of spongy parenchyma in Plate I, C. If the condition shown in that figure is compared with $\mathrm{A}, \mathrm{B}$, and C of Plate II the stages in the disintegration and destruction of the chloroplasts will be readily seen. At first the chloroplasts begin to lose the regular form, and the green coloring matter is diffused through the protoplasmic substance of the cell, while the protoplasmic bodies disintegrate into smaller granules and remain separate or are grouped together in irregular masses showing a paler and paler green as the effect of the manganese continues. In the final stages of the yellowing of the leaf every trace of green matter has disappeared and only small irregular granules of pale protoplasm are to be seen in the cells which previously carried normal chloroplasts. The conspicuous feature of the effect of manganese upon the growth of pineapple plants is the pronounced and peculiar yellow color of the leaves. Under the microscope the cause for this yellowing is found in the loss of the green coloring matter and in the slight tendency toward the yellowing of the cell wall and disintegrated protoplasmic substance under the influence of manganese.

In the normal leaf an ordinary iodin test shows the presence of starch granules in the protoplasmic bodies. Simultaneous with the etiolation of the chloroplasts the iodin fails to show the presence of starch. In the later stages of the yellowing of the leaves only occasional granules of starch are to be found here and there in the dis-

[Bull. 28] 
integrated cell contents of the spongy parenchyma. The amount of starch which is stored up in the stem of the pineapple, however, is still almost as great in plants growing on manganese soils as in normal plants.

The peculiar distribution of the chlorophyll exclusively at the lower side of the leaf seems to be characteristic of the family Bromeliaceæ, so far as we have had opportunity to observe. At any rate the chlorophyll is regularly distributed throughout the thickness of the leaf or as densely near the upper surface as near the lower surface in leaves of mango, Croton, Sapium, papaya, Monstera, sísal, Sansevieria, oleander, Calophyllum, Eucalyptus, Chrysophyllum, Agave americana, canna, Peireskia, banana, prickly pear, Cordyline terminatis, and vanilla. In' none of these plants, except a few in the early stages of growth of the leaves, is there any pronounced development of red coloring matter, which might serve to protect the chlorophyll, nor in any of the plants mentioned is the chlorophyll restricted to the lower surface of the leaf. It would seem from the observations which we have made that the pineapple and closely related species of the same family are particularly sensitive plants in this respect. The unusually rapid destruction of the chlorophyll bodies and the yellowing of the leaves of pineapples, as compared with other cultivated plants on manganese soils, also favors this view.

OXALATE OF LIME.

Chemical analyses oı various parts of the pineapple plant show that there is a much larger quantity of lime in plants growing on manganese soils than in those on normal soils. This finding is partly explained and further confirmed by the fact that when examined under the microscope all parts of such plants are found to contain enormously large numbers of the needlelike crystals of oxalate of lime. These crystals are especially numerous in the fruits, but are also relatively much more numerous in the leaves of pineapples turned yellow from the effects of manganese than in leaves of the normal green plants.

\section{OTHER VISIBLE EFFECTS OF MANGANESE.}

However the effect of manganese on pineapples and other plants may be explained, it seems not to be entirely due to the increased amount of manganese absorbed by pineapples on highly manganiferous soils, for the amount of increase of manganese in the ash is not sufficiently large to permit such a view to be held. A thorough search was made for the possible visible appearance of manganese in plants other than pineapples. Minute concretions of manganese were found on the ducts and sieve tubes in the roots of mango and strawberry. These concretions were readily dissolved by hydrochloric [Bull. 28] 
acid. The presence of citric acid in pineapples would tend to keep the manganese in solution, and this may explain the fact that no visible deposits of manganese could be found in pineapples.

In addition to the brown color of the protoplasm referred to above, it should be mentioned that the roots of pineapples growing on highly manganiferous soils show a darker brown color than in normal plants and that distinct brown patches appear on the upper surface of the leaves of plants during the later stages of yellowing. These brown areas may be sunken or elevated and the roughness of the surface seems to be due to the death of the tissue underneath and the consequent shrinking, thus throwing the surface into folds. The - brown patches are perhaps the results of sun scald, which apparently takes place more rapidly after the living tissues have been injured by manganese and the regulatory apparatus is thereby destroyed.

\section{THE CHEMISTRY OF THE PINEAPPLE PLANT.}

The development of a yellow color in the leaves of pineapples on certain soils of Oahu has become a matter of common observation. Investigations into the cause of this phenomenon have resulted in establishing a direct relationship between the occurrence of manganese in the soil and the yellowing of the pineapples. In 1909, 1 from a preliminary investigation, it was pointed out that the degree of yellowing is directly proportional to the amount of manganese in the soil, and that the manganese exists in the soil in a state of higher oxids, from which forms it readily becomes available to the roots of plants. It was further shown by the use of the Dyer method that the manganese is quite soluble. Subsequently it has been pointed out that the solubility of manganese in various dilute organic acids ${ }^{2}$ is very pronounced, and that its solubility in distilled water in some instances is greater than that of any other element, in the soil. It was further pointed out that the general metabolism of the pineapple, when grown on manganiferous soils, is considerably modified. In order to throw more light on this question, an extensive study of the chemistry of the pineapple plant has been undertaken in conjunction with the anatomical and physiological investigations.

The results obtained, it is believed, will enable a proper understanding of certain peculiarities already mentioned and afford a more exact chemical basis for a comprehension of the physiology of the plant, and also furnish some explanation for the peculiarities attending the presence of large amounts of manganese in the soil. In this study the mineral constituents of the several parts of the plant have been determined.

${ }^{1}$ Hawaii Sta. Press Bul. 23 ; Jour. Indus. and Engin. Chem., 1 (1909), pp. 533-538.

2 Hawaii Sta. Rpt. 1909, p. 63.

[Bull. 28] 
MANGANESE.

In this investigation a number of representative plants from highly manganiferous soil, on the one hand, and from normal soil, on the other, were separated into leaves and stalk, and after becoming thoroughly air dried were subjected to analysis. The ash was determined by incinerating over a free flame at a temperature weli below redness, then leaching with distilled water, according to the optional method of the Association of Official Agricultural Chemists for the determination of ash in plants. ${ }^{1}$ The several mineral constituents were determined in samples of the ash thus obtained. It should be mentioned in this connection that the percentages of sulphur, chlorin, and possibly phosphorus pentoxid, should not be considered as absolute, for the reason that partial volatilization may have taken place. In the case of phosphorus pentoxid, a number of determinations were made by the use of wet methods, and results closely agreeing with those secured from the ash were obtained, so that fair accuracy is believed to have been obtained. In any event, the results are comparable among themselves, and since it is for this purpose that they are submitted, their value is not greatly impaired.

The composition of the ash of leaves and stalk from the two classes of soil is recorded in the following table: ${ }^{2}$

Composition of pineapple leaves and stalk.

\begin{tabular}{|c|c|c|c|c|c|c|c|c|}
\hline & \multicolumn{4}{|c|}{ Leaves. } & \multicolumn{4}{|c|}{ Stalk. } \\
\hline & $\begin{array}{l}5 \text { months } \\
\text { old from } \\
\text { manganif- } \\
\text { erous soil. }\end{array}$ & $\begin{array}{c}5 \text { months } \\
\text { old from } \\
\text { normal } \\
\text { soil. }\end{array}$ & $\begin{array}{l}18 \text { months } \\
\text { old from } \\
\text { manganif- } \\
\text { erous soil. }\end{array}$ & $\begin{array}{c}18 \text { months } \\
\text { old from } \\
\text { normal } \\
\text { soil. }\end{array}$ & $\begin{array}{l}5 \text { months } \\
\text { old from } \\
\text { manganif- } \\
\text { erous soil. }\end{array}$ & $\begin{array}{c}5 \text { months } \\
\text { old from } \\
\text { normal } \\
\text { soil. }\end{array}$ & $\begin{array}{c}18 \text { months } \\
\text { old from } \\
\text { manganif- } \\
\text { erous soil. }\end{array}$ & $\begin{array}{l}18 \text { months } \\
\text { old from } \\
\text { normal } \\
\text { soil. }\end{array}$ \\
\hline Ash.................. & $\begin{array}{r}\text { Per cent. } \\
9.94\end{array}$ & $\begin{array}{r}\text { Per cent. } \\
7.14\end{array}$ & $\begin{array}{r}\text { Per cent. } \\
\mathbf{7 . 9 8}\end{array}$ & $\begin{array}{r}\text { Per cent. } \\
\quad 6.24\end{array}$ & $\begin{array}{r}\text { Per cent. } \\
8.86\end{array}$ & $\begin{array}{r}\text { Per cent. } \\
5.12\end{array}$ & $\begin{array}{r}\text { Per cent. } \\
7.78\end{array}$ & $\begin{array}{r}\text { Per cent. } \\
6.60\end{array}$ \\
\hline $\begin{array}{l}\text { Ash constituents: } \\
\text { Silica }\left(\mathrm{SiO}_{2}\right)_{3}\end{array}$ & 9.37 & 8. & 5. & 7.36 & 5.20 & 2 . & 1.72 & 2.84 \\
\hline $\begin{array}{l}\text { Alumina }\left(\mathrm{Al}_{2} \mathrm{O}_{3}\right) \\
\text { Ferric }\end{array}$ & 2.12 & 1.20 & 1.76 & .40 & .40 & 1.56 & 4.52 & 6.02 \\
\hline$\left(\mathrm{Fe}_{2} \mathrm{O}_{3}\right) \ldots$ & .81 & 1.11 & .96 & .48 & .60 & .70 & Trace. & Trace. \\
\hline $\begin{array}{r}\text { Manganese oxid } \\
\left(\mathrm{Mn}_{3} \mathrm{O}_{4}\right) \ldots \ldots \ldots . . . . . .\end{array}$ & 2.41 & 1.70 & 2.08 & 1.40 & .25 & .25 & .20 & .08 \\
\hline Lime $(\mathrm{CaO}) \ldots$ & 9. & 7.1 & $\begin{array}{r}25.66 \\
15.66\end{array}$ & 7.00 & 36.42 & 23.87 & 14.36 & 12.96 \\
\hline Magnesia (Mgö). & 5.70 & 7.60 & 7.91 & 6.98 & 2.60 & 5.82 & 7.75 & 5.78 \\
\hline Potash $\left(\mathrm{K}_{2} \mathrm{O}\right) \ldots$ & 21.09 & 22.97 & 18.86 & 22.86 & 16.79 & 24.18 & 32.26 & 33.01 \\
\hline Soda $\left(\mathrm{Na}_{2} \mathrm{O}\right) \ldots \ldots$ & 19.48 & 16.72 & 14.35 & 17.12 & 2.65 & 1.65 & 1.10 & .60 \\
\hline $\begin{array}{l}\text { orus pen- } \\
\left(\mathrm{P}_{2} \mathrm{O}_{5}\right) \\
\text { trio }\end{array}$ & 2.81 & 3.57 & 1.66 & 2.70 & 6.12 & 8.86 & 6.70 & 8.36 \\
\hline $\begin{array}{l}\text { Sulphur trioxid } \\
\left(\mathrm{SO}_{3}\right) \ldots \ldots \ldots \ldots\end{array}$ & 2.62 & 2.72 & 2.70 & 3. & 20.5 & 16.36 & 16.81 & 22.93 \\
\hline Chlorin (Cl)......... & 13.37 & 13.33 & 13.61 & 8.86 & 6.31 & 9.36 & 11.13 & 8.01 \\
\hline
\end{tabular}

These data show that there is a wide range of variation in the inorganic constituents of the plant. Considerable differences have been

${ }^{1}$ U. S. Dept. Agr., Bur. Chem. Bul. 107 (rev.), p. 238.

2 Analyses of the roots were not made, for the reason that it is very difficult to remove all traces of adhering soil from pineapple roots when grown in Hawaii.

[Bull. 28] 
observed in the percentages of the mineral elements in a given species of plant when grown under different environments, such as are afforded by different types of soil, climatic variations and latitudinal changes, and the exact significance of the variations thus induced is not fully understood; but the variations in the composition of pineapple ash, herein reported, especially as regards the lime, magnesia, and phosphorus pentoxid, are believed to have special importance. The significance of these data has been fully interpreted in a previous publication which is devoted to a comprehensive study of the function of manganese in plant growth. ${ }^{1}$

At this time it is wished merely to call attention to the excessive amounts of lime and the relatively smaller amounts of magnesia, as well as a correspondingly smaller percentage of phosphorus pentoxid, in the plants from manganiferous soils. As previously mentioned, the occurrence of calcium oxalate crystals is much more abundant in the chlorotic plants; in fact the presence of calcium oxalate forms one of the noticeable characteristics in all parts of these plants; and while this so-called by-product occurs in considerable amounts in normal pineapple plants, the amount is in great excess in the chlorotic plants. Various authorities have discussed the occurrence of calcium oxalate in plants, and in general they are agreed that one of the functions of lime in plants is to neutralize the acids formed as a result of metabolism. One of the principal acids thus formed is oxalic, which has been supposed, by various authorities, to result from at least two different sources: (1) It may arise from a decomposition of carbohydrates during plant respiration; and (2) it is thought to be derived, in some instances, from the breaking up of protoplasm.

In chlorotic pineapples there have been observed a general disintegration and breaking up of the organized structure of the protoplasm and the complete disappearance of the chloroplasts. With this there is a simultaneous appearance of oxalate of calcium. From these observations the conclusion may be drawn that the excessive amount of oxalic acid in chlorotic pineapples results from a decornposition of the protoplasm itself, and that its neutralization and subsequent crystallization is made possible through the presence of abnormal amounts of lime in the cell sap.

\section{THE RIPENING OF THE PINEAPPLE FRUIT.}

As has been clearly shown by numerous chemical analyses made at this station, it is a peculiar feature of the ripening of the pineapple fruit that no increase in the amount of sugar takes place during the ripening process if the fruit has been removed from the plant. It is apparent, therefore, that the materials which are transformed into sugar are to be sought in other parts of the plant than the fruit.

[Bull. 28]

1 Hawaii Sta. Bul. 26. 
Sections were made through all parts of the pineapple plant from the base of the stem to the crown with the result that the distribution of starch is found to be strictly in harmony with the chemical findings of the ripening of the fruit. In the dead and partially decomposed basal end of the stem there is relatively little starch, and that which is present is for the most part removed some distance from the fibrovascular tissue. The parenchyma cells in the stem, with the exception of the dead base, are completely filled with starch; in fact, these trunks apparently contain as high a percentage of starch as potatoes or other plant structures used in the commercial manufacture of starch. The station has planned some experiments to show whether old pineapple stumps which have heretofore been thrown away may be used commercially for obtaining starch. The storage of starch continues upward to the attachment of the uppermost regular leaves, where it suddenly ceases. As sections are made in the fruit stem above this point, it is found that starch is almost entirely absent up to the point where the small bracts are attached to the base of the fruit. Here, especially in normal plants. the accumulation of starch is quite conspicuous.

In the very young fruit at flowering time small granules of starch may be found at the base of the bracts under each eye and occasionally throughout the substance of the fruit. At the base of the crown leaves there is a considerable accumulation of starch and a few granules are found in the core. The crown in young fruits contains a large quantity of starch.

It is a peculiar fact that old stumps connected only by means of a dead stem with ratoon stems contain fully as much starch as the latter. The old stumps are known to be capable of producing pineapple plants and have been especially recommended for highly manganiferous soils. It is likely that in such cases the plants are able to develop from the large supply of starch found in the stems. Starch is quite abundant throughout the length of all normal leaves. When the fruit is about half grown it contains only an occasional starch grain here and there just underneath the green epidermis. In ripe fruit it is almost impossible to find even a trace of starch in any part of the fruit. It is evident from this distribution of starch that the source of material to be modified by hydrolysis into sugar is almost exclusively outside of the fruit. The few granules of starch found under the green epidermis of unripe fruit and the small quantity of starch in the crown are insufficient to make any practical addition to the sugar content of pineapples which are allowed to ripen after removal from the plants.

In this connection it is interesting to note the fact that some pineapple growers consider the crown as a parasite of the fruit or as

[Bull. 28] 
growing at the expense of the fruit. Experiments in removing the crown from young fruits indicate that the core is thereby rendered smaller and that the fruit is larger in cross diameter at the top, assuming a more cylindrical shape. The facts which have been stated regarding the distribution of starch in the pineapple plant and therefore of the possible sources of sugar in the ripening of pineapple fruits are in harmony with the findings of Hume and Miller, ${ }^{1}$ that the sugar content is higher at the base of the fruit than in the crown and higher nearer the core than at the surface. This would indicate that the sugar enters the fruit through the fruit stem at the base.

While pineapples in ripening after removal from the plant do not develop any higher sugar content than they had at the time of removal, they nevertheless undergo all the other processes which are characteristic of ripening. The color changes are the same as those in fruits which ripen on the plant and the fruit becomes soft and juicy. It is a matter of common knowledge that only a small amount of juice runs out of the cut surface of a green pineapple while much larger quantities escape from similar cuts from ripe pineapples. This is at least partly explained by reference to $\mathrm{D}$ and $\mathrm{E}$ of Plate II. In $\mathrm{D}$ is seen a cell from the soft pulp of a completely ripened pineapple. The cell wall is thin, delicate, and is easily torn. In fact the walls here and there in ripe fruits are completely broken down in the ripening process so that some of the larger cavities may be parts of what was previously several cells. In the green fruits, on the other hand, as shown in E, Plate II, the cell walls of the pulp tissue of the fruit are much thicker. The thickening of these cell walls is composed of irregular masses of a collagenous nature. During the ripening process this material appears to be dissolved, leaving the thin cell wall of the delicate tissue which is characteristic of the pulp of ripe fruit.

\section{THE CHEMISTRY OF RIPENING.}

The physiology of the pineapple plant indicates some peculiarities belonging to this plant, and which are different from those of most, fruits. The chemical changes taking place during ripening have previously received some attention at this station, ${ }^{2}$ and in order to have a more strict chemical basis for the interpretation of the physiology already outlined, it is thought that a further discussion of these data will be of interest. It has been shown that the average composition of the green fruit, just before the beginning of the ripening process, is as follows: Acidity, as sulphuric acid, 0.39 per cent; fiber,

1 Florida Sta. Bul. 70.

${ }^{2}$ Hawaii Sta. Rpt. 1910, pp. 45-50 ; Jour. Indus. and Engin. Chem., 3 (1911), pp. $403-405$.

[Bull. 28] 
0.17 per cent; solids in the juice, 6.89 per cent; total hydrolyzable carbohydrates, expressed as invert sugar, 5.80 per cent; reducing sugars, as invert sugar, 3.29 per cent; sucrose, 1.72 per cent; and total sugars, 5.01 per cent.

The point of special interest in these data is the small percentage of sugars in the green fruit. It should be borne in mind in this connection that the above data were secured from fully grown fruit which, so far as could be judged, were just at the beginning of the ripening process. In addition, these analyses were made by the use of the fruit itself, rather than the juice. While the reducing sugars and sucrose make up a small percentage of total sugars the hydrolyzable carbohydrates, which were determined by boiling samples of the fruit with hydrochloric acid, show that the storage of reserve material in the growing pineapple is slight, and if severed from the plant at this stage it can not possibly develop a normal sugar content in subsequent ripening. Pineapples gathered green and allowed to ripen afterwards were found to have the following average composition: Acidity, 0.58 per cent; fiber, 0.22 per cent; solids in the juice, 6.45 per cent; reducing sugars, 1.22 per cent; sucrose, 3.90 per cent; total sugars, 4.12 per cent; and total hydrolyzable carbohydrates, as invert sugar, 4.35 per cent.

The principal changes that take place in this process are the conversion of reducing sugars into sucrose, and a slight increase in acidity. 'There is a pronounced development of flavor and a general softening of the tissues, but the true fiber is not materially changed. The average composition, when approximately one-fourth ripe, was found to be as follows: Acidity, 0.65 per cent; solids in the juice, 8.68 per cent; reducing sugars, 2.74 per cent; sucrose, 4.42 per cent; total sugars, 7.16 per cent; and when half ripe the fruit contains: Acidity, 0.65 per cent; reducing sugars, 2.97 per cent; sucrose, 6.74 per cent; and total sugars, 9.71 per cent. When allowed to ripen normally on the plant, the composition was found to be as follows: Acidity, 0.74 per cent; reducing sugars, 4.23 per cent; sucrose, 7.88 per cent; and total sugars, 12.11 per cent.

The composition at the several stages of ripening shows that there is a rapid accumulation of sugars, especially sucrose, and a slight increase in acidity during the development of the fruit. From a study of the physiology of this plant we can better understand the analytical data. It has been shown that the normal pineapple plant stores up large amounts of starch in the stalk and base of the leaves, whereas only faint traces of starch could be detected in any portion of the fruit at any stage of its development. The fruit stem was found to contain small quantities of starch; also there are scattering granules in the cells immediately adjacent to the epidermis. These cells were

[Bull. 28] 
also found to contain a small amount of starch adhering to the chloroplastids. The deeper-lying tissues rarely contain any starch; neither was dextrin detected in more than mere traces; and from the results of acid hydrolysis we may conclude that the green fruit contains no substance of importance that is capable of giving rise to sugars during subsequent ripening.

The chief carbohydrates produced in the plant, then, may be considered to be of the nature of sugars and starch, and these may be looked upon as being produced somewhat as follows: The protoplasm transforms carbon dioxid and water into sugars by the intervention of chlorophyll, just as is done in all plants. The excessive accumulation of sugar in the chlorophyll-bearing cells is prevented by its transformation into starch, which, in turn, is stored principaliy in the stalk. During the vegetative growth of the fruit relatively small amounts of carbohydrates are transferred to it, but in the normal ripening process there is an enormous accumulation of sugars in the fruit, which sugars are derived from the carbohydrates previously stored as starch in the stem.

Normally, pineapples stand almost perpendicular and are somewhat protected from the direct rays of the sun by the crown. Occasionally there are to be observed in the fields pineapples that have weak stems, which results in the fruit becoming turned over and exposing one side to the direct rays of the sun. The pineapples that are thus exposed become blanched on the upper side, which appears to mature earlier than the lower and more protected surface. Such pineapples also are less palatable in the upper and exposed portion.

With a view of determining the composition of such fruits a number of analyses have been made. These pineapples were sampled in such way as to secure one portion from the upper side and one from the lower side. Partial analyses of these portions are recorded as follows:

The composition of upper and lower portions of pineapples.

\begin{tabular}{|c|c|c|c|c|c|c|c|c|}
\hline \multirow{2}{*}{$\begin{array}{l}\text { Serial } \\
\text { No. }\end{array}$} & \multirow{2}{*}{$\cdot$} & \multirow{2}{*}{$\begin{array}{c}\text { Acidity } \\
{\text { as } \mathrm{H}_{2} \mathrm{SO}_{4}} .\end{array}$} & \multirow{2}{*}{$\begin{array}{c}\text { Reducing } \\
\text { sugars } \\
\text { calculated } \\
\text { as invert } \\
\text { sugar. }\end{array}$} & \multirow{2}{*}{ Sucrose. } & \multirow{2}{*}{$\begin{array}{c}\text { Total } \\
\text { sugars. }\end{array}$} & \multicolumn{3}{|c|}{ Polarization. } \\
\hline & & & & & & Direct. & Invert. & $\begin{array}{l}\text { Tempera- } \\
\text { ture. }\end{array}$ \\
\hline $\begin{array}{l}119 \\
119 \\
120 \\
120 \\
121 \\
121 \\
122 \\
122\end{array}$ & 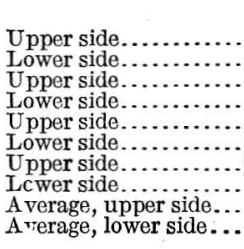 & \begin{tabular}{|r|} 
Per cent. \\
0.51 \\
.51 \\
.40 \\
.74 \\
.88 \\
.98 \\
.72 \\
.55 \\
.63 \\
.69
\end{tabular} & $\begin{array}{r}\text { Per cent. } \\
3.06 \\
4.35 \\
4.00 \\
3.44 \\
3.33 \\
2.98 \\
4.17 \\
4.54 \\
3.64 \\
3.83\end{array}$ & $\begin{array}{r}\text { Per cent. } \\
5.58 \\
8.42 \\
4.81 \\
6.17 \\
6.78 \\
8.41 \\
7.48 \\
8.45 \\
6.16 \\
7.86\end{array}$ & $\begin{array}{r}\text { Per cent. } \\
8.64 \\
12.77 \\
8.81 \\
9.61 \\
10.11 \\
11.39 \\
11.65 \\
12.99 \\
9.80 \\
11.69\end{array}$ & $\begin{array}{r}{ }^{\circ} V . \\
4.1 \\
6.4 \\
3.4 \\
4.7 \\
4.9 \\
6.4 \\
5.6 \\
6.3 \\
\ldots . . .\end{array}$ & $\begin{array}{l}{ }^{\circ} V . \\
-3.0 \\
-4.3 \\
-2.8 \\
-3.1 \\
-3.7 \\
-4.3 \\
-4.0 \\
-4.5 \\
\cdots\end{array}$ & $\begin{array}{r}{ }^{\circ} C . \\
31.0 \\
31.4 \\
31.7 \\
32.5 \\
31.7 \\
30.8 \\
28.6 \\
29.7 \\
\cdots \\
\cdots\end{array}$ \\
\hline
\end{tabular}


These data show that a considerably greater:amount of sucrose is deposited in the lower and more protected portion of the fruit. This may be partially accounted for by the fact that the ripening process is abnormal in character and more hastened in the blanched portion of the fruit. There seems to be no evidence for believing that the hydrolysis of starch in the stalk and the diffusing of sugars to the fruit continues after the fruit becomes thoroughly ripe, even if it be left attached to the plant. The period of transference of sugars to the blanched portion of such pineapples, therefore, is shorter and consequently it should contain less sugars. In addition, osmosis may in some way be modified by the effects of direct rays of the sun on the fruit.

\section{SUMMARY.}

The root system of pineapples is very variable and particularly sensitive to adverse soil conditions. When grown in manganiferous soil the roots are less extensive and the ends of the roots are characterized by, the development of swollen tips, the appearance of which seems to mark the cessation of the lateral growth of the roots, death and decay immediately following their development. The cells immediately beneath the epidermis of the roots are also somewhat more brown than are normal roots.

The stem of pineapples serves as a repository for starch and contains large amounts of this substance.

The leaves of pineapples in common with other members of Bromeliaceæ contain several rows of palisade cells which contain nothing but cell sap, and the chlorophyll is confined to the spongy parenchyma in the lower three-fifths of the leaf. The fruit contains only faint traces of starch during early growth and when it reaches maturity starch is absent from it.

The most conspicuous effect of manganese on this plant is seen in the bleaching of the chlorophyll which first begins to fade, the chloroplasts lose their organized structure, and later the color disappears altogether. Oxalate of calcium is much more abundant in pineapple plants growing on manganiferous soils. The ash of such plants also contains considerably more lime and less phosphorus pentoxid and magnesia than when grown on normal soils.

During the growth of the fruit relatively small amounts of sugars are stored in it, but within the short period of normal ripening there is a rapid accumulation of sugars in the fruit. Pineapples gathered green do not develop a normal sugar content in subsequent ripening. The sugars of the fruit are derived from the starch previously stored $n$ the stalk.

[Bull. 28] 
The study of the pineapple shows that it is exceedingly sensitive to adverse physical and chemical conditions in the soil. So far as is known at present, there is no really satisfactory program by which pineapples can be grown on highly manganiferous 'soils. It seems best to use such areas for other crops less sensitive to manganese. The best method of handling pineapples on manganiferous soils consists in applying soluble phosphates and planting old stumps instead of suckers.

[Bull. 28]

ADITIONAL COPIES of this publication A may be procured from the SUPERINTENDENT OF DOCUMENTS, Government Printing Office, Washington, D. C., at 20 cents per copy

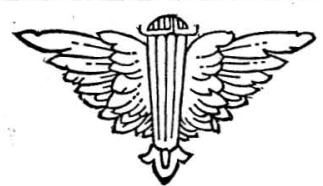

